\title{
MAYA INTIMACY WITH THE MOUNTAINS: PILGRIMAGE, SACRIFICE AND EXISTENTIAL ECONOMY
}

\author{
JAN KAPUSTA \\ PhD, Assistant Professor \\ Department of Philosophy and Social Sciences \\ Philosophical Faculty \\ University of Hradec Králové \\ nám. Svobody 331, 50003 Hradec Králové, Czech Republic \\ e-mail: kapusta.jan@seznam.cz
}

\begin{abstract}
In this paper, I present two very different and yet very similar ethnographic examples of mountain-related pilgrimage and sacrifice ritual performed by the presentday highland Maya. The question I ask is why the sense of sacredness, animation and power of the mountains endures among the traditionalist as well as Pentecostal Maya in spite of the extensive transformations of the world today. In so doing, I examine the native concept of the mountain not merely as a social or cultural representation, but as an expression of everyday lived experiences and existential relationships between people and the physical and spiritual world they inhabit. Finally, I argue that the experience of interaction, communication and intimacy between the Maya and their mountain deities can be best defined as a dynamic participation in the course of the world - an existential economy of 'working the world'.
\end{abstract}

KEYWORDS: Maya cosmology • pilgrimage ritual $\bullet$ cultural continuity $\bullet$ life-world - existential anthropology

\section{IN T RODUCTION}

In current anthropology, 'continuity thinking' does not have such a good reputation as in earlier times. Instead of the old-fashioned theory of cultural continuity and syncretism, a language of radical change, rupture and discontinuity is required to explain the phenomenon of Christian conversion (Robbins 2007). The rejection of old indigenous customs as a prerequisite for the new faith and life is said to be particularly present in Protestantism, which is rapidly gaining ground among the native populations of Latin America. Indeed, costumbre - which literally translates as custom and which means a set of rites inherited from the ancestors that need to be performed - is rejected very resolutely by most Protestant converts. However, ethnographers of Mexico and Central America often find that new evangelical - especially Pentecostal - thoughts as well as practices still contain much of the ancient indigenous culture (Dow and Sandstrom 2001). Moreover, the costumbre as such is generally considered to be the product of a 
dynamic dialogue between indigenous American and imported Christian religiosity that has been developing over centuries and that is structured in a strained relationship between Indians and Ladinos (non-Indians) and characterised by a high degree of hybridisation (Watanabe and Fischer 2004).

Against this backdrop, my attempt to demonstrate the persistence of certain Maya visions related to powerful mountains and their masters might seem of little use. Why defend continuity again? However, in fact it is not my intention to argue for adopting the cultural continuity approach, at least not in its temporal dimension. Nor do I wish to argue for the traditional rival approach of political economy, which focuses on social difference. My contention is that Maya ritual practice, associated with specific cosmology and perceptions of mountains, should not be seen as growing solely out of cultural patterns (traditional norms, ideas and concepts) and political history (the social and ethnic structure), but also out of everyday lived experience and existential relationships between people and the physical and spiritual world they inhabit. A great theoretical divide dominates the ethnology of the Maya: a divide between primordialism (essentialism), which involves the constant search for cultural continuity and the 'real' Mayaness, on the one hand, and historicism (constructivism), which involves focusing on ethnic conflict and 'made-up' Mayaness, on the other (Watanabe 1992; Fischer 2001). I suggest that the conflict between cultural and social reductionism cannot be resolved by denying or confirming the one or the other position, but that the gap needs to be bridged by proposing a standpoint to refer not only to the cultural or social representation of the world, but also to the existential representation of the life in the world.

In this paper, I examine pilgrimage and sacrifice rituals associated with mountains, as performed by the present-day highland Maya. I draw on a total of six months of fieldwork consisting of participant observation and informal interviews, which I conducted in Maya communities in the Department of Huehuetenango, Guatemala, in 2009 and 2013. The question I will ask in relation to the two particular ethnographic examples of pilgrimage discussed here is why the sense of sacredness, animation and power of the mountains endures among the traditionalist as well as Pentecostal Maya in spite of the extensive transformations of the world today. It is the native concept of the mountain as such that, in my view, requires specific attention, not only in its cultural and social, but also in its phenomenal and existential dimension. As is well known from practice theory, the ritual is not a mere representation of the worldview; the ritual is an enactment of it (Kray 2007). Through ritual, relationships between the Maya and other peoples, saints, crosses, mountains and other beings of the world are put into practice and become real. Through ritual, an intimate relationship with these other beings is achieved, creating a basis for the knowledge and behaviour that integrate humans into (not just human) society and the (not just physical) cosmos, characterised by the existential moment of mutual dependence.

With respect to intimacy, my concern in this paper is not possession or transformation. This is not to say that such forms of intimacy between humans and non-humans are absent in Maya culture - quite the contrary: the ethnology of the Maya abounds with examples of practices in which spiritual possession or transformation into animals play a crucial role. Here, however, I wish to focus on those expressions of intimacy in which humans seek contact and negotiate with non-humans and thereby deal with fundamental existential issues of life. In such a context, intimacy is the product of con- 
tinuous co-existence rather than radical change. The question of being is universal, as argued by Michael Jackson (2005: xv), and constitutes a starting-point in the attempt to investigate human life-worlds: "[the] task is thus to explore human being-in-the-world through our ever-changing capacity to create the conditions of viable existence and co-existence in relation to the given potentialities of our environment". The concept of 'emotional economy' put forward by Fenella Cannell (1999), who has described human and non-human encounters as marked by a large degree of ambiguity, tension and uncertainty, is also of high relevance in this context.

Indeed, expressive culture is a live and dynamic practice that grows out of a specific experience-based attitude to the world (Cook 2000). Thus, I regard Maya ritual as an expression of how humans work the world, which has a cyclical nature and in which, as a result, bad things can happen. It is the existential moment of being-in-the-world - a world which is not a constant given, nor something definitive nor a matter of course that makes the shamans perform the obligations that they feel are needed in the face of a world whose harmony is constantly at risk (MacKenzie 2009). At a general level, therefore, this paper is partly a response to the calls for a phenomenological anthropology (Jackson 1996; Desjarlais and Throop 2011) and partly an echo of the current anthropological interest in the study of ontology (Scott 2013) and existential matters (Jackson 2005).

In the first part of the study, I present two brief ethnographies of Maya pilgrimage: the journey to the mountain of K'utataj, which is organised to mark the Maya New Year, and the journey to the volcano of Santa María, which is a form of Pentecostal Maya fasting and prayer service. In the second part, I propose another way of understanding the masters of the mountains, who are often thought to be of Ladino ethnicity. As in the case of the 'diabolic' mine owners of the Andes and the Maya 'Judas' Maximón, the way these beings are depicted seems to reflect the unequal power relations between Indians and Ladinos and the associated subordination and resistance. Nevertheless, I would like to emphasise that Maya mountain deities also derive their meaning from the mountains as such, that is, from their potentially existential importance in providing livelihood and fostering life. In the third part, I discuss Maya deities, saints, crosses and mountains that are perceived as autonomous living beings endowed with consciousness, volition and the ability to act. Drawing on the example of sacrifices to the mountains, I argue that, in the world of the Maya, individual interdependent beings need to meet their obligations and commitments and, in so doing, contribute to a universal existential economy. It is this existential need to pray and sacrifice for a successful continuation of the world that defies social and cultural reductionism and leads to the exploration of the practice in which humans and non-humans are active agents in the field of relationships among all beings participating in the course of the world.

\section{MOUNTAIN PILGRIMAGES AMONG MAYA TRADITIONALISTS AND PENTECOSTALS}

The importance of journeys to mountains and caves is well documented in the ethnology (for example Reina 1966; Wilson 1995; Piedrasanta Herrera 2009) as well as archaeology (for example Brady and Veni 1992; Brady and Rissolo 2006; Pugh 2009) of the 
Maya. Surprisingly, though, this kind of pilgrimage is not exclusive to the customs of Maya traditionalists; it can even be found in Pentecostal religious practice. Mountains continue to be very important in contemporary Maya thought, in spite of the considerable religious and cultural changes resulting from the conversion to Protestantism in general and Pentecostalism in particular. ${ }^{1}$ In this section, I will provide two brief ethnographic examples of Maya mountain pilgrimage: the first concerns a pilgrimage in a traditionalist Akatek community inhabiting the isolated area of the Sierra de los Cuchumatanes; the second concerns a pilgrimage in the well-connected area of the Santa María volcano, which attracts traditionalist and revivalist Maya shamans as well as Pentecostal converts. I will then briefly discuss the nature of cultural continuity and rupture as manifested in the given context.

The pilgrimage to the mountain of $K^{\prime}$ utataj, which takes place to mark the Maya New Year, was one of the most intense and impressive fieldwork experiences during my stay in the western highlands of Guatemala. ${ }^{2}$ The journey starts in the settlement of Chimbán, which is the religious centre of all Akatek traditionalists inhabiting the municipalities of San Miguel Acatán and San Rafael La Independencia in the Department of Huehuetenango. In 2013, when I witnessed the ritual, the date of the advent of the Maya New Year was set at February 17 (10 Chinax in the Maya calendar). I accompanied two locals, Manuel, the rezador (prayersayer or shaman), and Félix, his ayudante (assistant), who happily consented to my participation in the pilgrimage. The pilgrimage started the day before the Maya New Year. In the morning, after the traditional all-night vigil, a sacrificial turkey was taken to a wicker cage, which Manuel loaded on to his back using a mecapal (tumpline). In the presence of other rezadores and principales (elders), we left the ordenanza house (ritual dwelling), marched past the church and then - already alone - walked out of the settlement.

At about noon, we reached the mountain of K'utataj, the goal of the first day's journey. José, a helper, who had carried all the requisites up the slope, had already been waiting for us at a small shrine surrounded by a pine forest. The afternoon was devoted to practical matters - collecting firewood, preparing our night's lodgings - as well as discussion and rest. It was not until midnight when we entered the shrine, dimly lit by a white candle, in order to perform the main ritual. Manuel untied the turkey and slashed its throat before the cross, so as to let its blood drip into the prepared bowl. In the meantime, Félix had prepared pom (pine resin chips), which Manuel dipped into the turkey's blood and Félix then wrapped in green leaves that had been picked beforehand. Twelve packages were created this way; the first one was lit before the main cross, along with a little bit of pom and a small wax candle. The next package was meant for the second cross inside the shrine, and the subsequent three were to be used for the cross outside and for two small witz (mounds of stones), respectively. The remaining seven were meant for other witz to be visited on the next day. Manuel then came back for the dead turkey, took it gently in his hands, tenderly stroked its feathers and pressed its head down on to its breast. Next, he took the turkey outside, placed it on a designated spot and covered it up with stones.

In the morning, we set out on our way back to Chimbán. Along the journey, Manuel had to visit the remaining seven witz to perform the costumbre. The course of the ritual was always the same: Manuel lit candles, pom and the sacrificial package, waited until the fire flared up, and then we drank aguardiente (cane liquor) together from the bot- 
tle. Chinax, the new Year Bearer, generally thought to provide favourable conditions, started his rule. ${ }^{3}$ In Chimbán, the día de ora - the day of the particular Year Bearer and of prayer - was honoured by a vigil and a special walk around sacred places, in keeping with the custom. At noon, a festive pinol (pepper sauce with chicken) was served, along with tortillas and chilli. This is the way in which the Akatek rezadores - whose job it is to pray for rain, good crops and the prosperity of the community as a whole, as well as to help individuals in need (see Siegel 1941; Deuss 2007) - ritualise the advent of the Maya New Year and the beginning of the next vegetation cycle. The ritual draws its meaning from the agricultural year. It is understood to be and experienced as an existential need: prayer and sacrifice are required for the good harvest and the successful continuation of the world.

I also encountered similar ideas of the sacredness, animation and power of the mountains on another occasion. Surprisingly, it was during a Pentecostal reunión (religious meeting). As is well known, Protestant churches - and various Pentecostal churches in particular - have spread rapidly in Mexico and Central America (Dow 2005) and have had an important impact on Maya culture as well (Annis 1987). In the traditional Maya areas in the western highlands of Guatemala, there is a popular Pentecostal religious ritual: the ayuno (fasting). Having stayed in Quetzaltenango for a few days, I intended to walk up the volcano of Santa María. During the trek, I met a K'iche' man and his daughter from the nearby municipality of Cantel. I was told that they were attending the ayuno in order to cure the girl. In the morning, they had not eaten and had walked the long journey to pray on the volcano - they had taken on the commitment to make a sacrifice (poniendo ofrenda). On the summit of the volcano, several dozen believers gathered to wait for the beginning of the ceremony, squatting on the ground and praying. Since I had come with a member of the group, I was cordially welcomed by the Pastor and invited to participate in the meeting. The ceremony lasted for about two hours and consisted of prayers and praise to the Lord. In an emotionally charged atmosphere, people cried and implored God. Some of them - especially the women - were trembling, jerking, shouting and speaking in tongues, which was evidence that there was the intimate presence of the Spirit of the Lord.

When descending the volcano, I realised how much the traditionalist and Pentecostal ceremonies had in common. On the one hand, there are traditionalist Maya pilgrimages to mountains where the sacrifice is made in order to ensure good weather, good crops and good fortune in the year to come. On the other hand, there are Pentecostal Maya ayunos, which are perceived as sacrifices and which provide a platform to ask for whatever is needed in life, including good health and prosperity. Of course, mountains, hills and volcanoes are the pilgrimage sites where communication with the divine takes place and where problems, wishes and dreams are articulated. But although the mountains are sacred and animated for traditionalists, they should not be for Pentecostal or Protestant Christians. Unexpectedly, my new friend himself began to speak about the dueño del cerro (master of the volcano). During the journey, he told me the story of how he had once met him in the shape of a bull and showed me the place where it had occurred.

The belief in the power of mountains was documented once again when my new friends requested a favour of me. On the summit of the volcano, they asked me for a photograph; I agreed and promised to bring it to Cantel. I fulfilled the promise by visit- 
ing them in their house a few days later. After a pleasant stay there, the man presented me with a piece of paper bearing the name of his daughter and asked me for another favour - to keep it and take it to an important mountain in Europe. Praying on the summits, I was assured, is the proper thing to do to obtain healing. The vision of powerful mountains and their masters apparently persists among the Maya, even if they consider themselves evangélicos. Recent anthropology of Christianity (and Protestantism in particular) has conceptualised the religious conversion as a 'rupture', putting emphasis on the discontinuity between the indigenous culture and the new faith, in contrast to earlier interpretations that had stressed, in one form or another, continuity and syncretism (Robbins 2003; 2007). Protestants are said to reject old beliefs and customs to begin new lives in a world of different logic. This is clearly at odds with the culturally syncretic world described by most anthropologists.

How complete the break with the past is naturally depends on specific social and individual circumstances. In some areas, anthropologists find remarkable similarity between traditional native customs and new evangelical beliefs and, as a result, tend to stress cultural continuity. Garret W. Cook (2001), for instance, argues that the Yukatek have preserved several old-style values and forms of social organisation after converting to Pentecostalism. According to him, Pentecostalism is compatible with the traditional visionary, divinatory and shamanic religion of the Maya. Abigail E. Adams (2001) has shown what might be the closeness between a Baptist woman's trance and Q'eqchi' traditionalists' receiving messages from the mountain spirits. Toomas Gross $(2009$; 2012) observes that, in the indigenous Zapotec communities of Oaxaca, various Protestant - especially Pentecostal - groups relatively easily adapt to, rather than reject, local customs and practices. His conclusion is that the transformative role of Protestantism should not be exaggerated. However, at the same time, all these ethnographers insist that there is a clear rejection of much of traditional thought and practice, which the Protestant Maya refused to incorporate into their worldview.

In sum, the converts have rejected many aspects of costumbre, while some of its fragments - consciously and unconsciously - survive. As Matthew Engelke (2004: 106) concludes, "We stand to gain from the language of breaks not because it replaces the language of continuity but because it complements it". In this article, my intention is not to deny the personal accounts and understandings of religious conversion and of new life and identity; on the contrary, I would like to take them even more seriously. The man I talked to at the religious meeting on the summit of the volcano of Santa María claimed to be an evangélico and, at the same time, a believer in the mountain masters. Under the discourse of continuity, one could argue that his evangelical belief is a sort of surface layer covering ancient Maya culture; under the discourse of discontinuity, one could argue his attitude to be to some degree schizophrenic or that he is ignorant of the new doctrine. Nevertheless, in so doing, one would be judging his attitude based on a metrics completely alien to him - either our belief in an essential Maya culture, or our belief in a pure evangelical theology. From his own point of view, however, his belief is coherent and absolutely sensible.

The similarity between Maya traditionalist and Pentecostal pilgrimages, with mountains as their common denominator, raises the following question: where does the interest in and fascination with the mountains come from? To answer that question, I would suggest that we should - instead of focusing on continuity or discontinuity of social 
structures and cultural patterns that vary significantly over time - pay attention to the thought and practice based on everyday experience and related existential concerns. However, before presenting my attempt in this respect, I would like to discuss the most common anthropological interpretation of the mountain masters, the one which imbues them with political meaning resulting from the ethnic differences and unequal power relations.

\section{LORDS, DEVILS AND JUDASES}

One of the prominent aspects of the Maya concept of mountains is that they have an ethnicity. Various Maya ethnic groups frequently tend to regard the ajaw - the 'lords', 'owners' or 'guardians' of the mountains - as Ladinos (for example Siegel 1941: 67; Oakes 1951: 93; Watanabe 1990: 141-143). The Mam describe the mountain lords as persons with light skin and fair hair with whom famous hunters or those who yearn to gain a lot of money enter into a pact under which they have to work the plantations within the mountains (Wagley 1957 [1949]: 186). The Q'eqchi' describe the guardians of the mountains as tall, fair and bearded beings, reminiscent of European priests or German land-owners; just as the Germans of the past, these patrónes, too, can eat their Indian workers (Wilson 1995: 57). The mountain lords therefore resemble Ladinos not only in their physical appearance, but also as being owners of the land and plantations on which the Indians need to work. Just as Ladinos, the owners of mountains are rich, powerful and unpredictable. They bring both good and evil: they can flood humans with game or money, while at the same time requiring hard work from, punishing or even eating them.

The idea of mountain lords is not limited to the Maya cultural area. Re-interpreting the ethnography of the ritual and folklore of Bolivian miners (Nash 1979) and drawing on Marxist doctrine, Michael Taussig (1980) considered the cosmology of the Andes as an Indian reflection of the immorality of the capitalist economy. Taussig argues the differences between pre-capitalist rural agriculture and capitalist mining industry to be personified in native deities, with Pachamama (Mother Earth, the guardian of agricultural production) representing the exchange of gifts, and Tío (Uncle, the guardian of mining production) representing the exchange of goods. Since Tío tends to be depicted as a devil, for Taussig he is the personification of the evil ascribed by the Indians to the unnatural economy based on the proletarisation of work and commodification of products. However, Michael J. Sallnow (1989) pointed out the existence of such 'unnatural' economy in the past and outside of mining as well. He argued that a 'pact with the devil' in the form of a contract between people and the owners of the mines should be understood as merely an extreme case of the culturally defined concept of blood sacrifice in the agricultural ritual. Moreover, Olivia Harris (1989) showed mining and agriculture not to be two different categories in native thinking: the minerals are in fact thought of as 'growing' in a way similar to potatoes or cattle and the 'fertility' of the mines is an integral part of the fertility of the soil. "The devils are the source both of fertility and wealth, and of sickness, misfortune, death. They are unpredictable and very powerful, a bit like wild animals, to which they are likened and whose 'owners' they are." (Ibid.: 251) The sharp distinction between agriculture and mining or between the 
exchange of gifts and the exchange of goods, linked to a moral judgment and materialised in the symbolism of the 'pact with the devil', therefore seems to be characteristic of the cosmology of the Marxists rather than that of the natives of the Andes.

The Maya view of the mountain guardians, too, is more complex than the ideological shorthand would suggest. Richard Wilson (1995: 58) notes that the Q'eqchi' ascribe both Ladino and Indian attributes to the mountains (these do not, for instance, speak Spanish) and that the mere likening of the lords to landowners does not automatically imply their sameness and identity. "Each tzuultaq'a is both a Maya and a white 'boss"', states Wilson (ibid.: 53), concluding that, "The important attributes of the tzuultaq'a figure, then, are its historical nature and its multiplicity of interwoven dualisms that encompass, without resolution, representations of indigenous and nonindigenous identities" (ibid.: 61). Comparing the saints (whose identity is seen as having more Indian traits) and the mountains (whose identity is seen as having more Ladino traits), as perceived by the Mam, John M. Watanabe (1992), also stressed that the distinction is not one of essential nature (Indian/Ladino, friend/enemy, good/evil), but of a degree of proximity and familiarity, on the one hand, and of distance and alienation, on the other. In this respect, identity is rooted in the spatial perception of the world and has a dialectic character derived from the nature of the social relationships and the corresponding modes of behaviour: "In this sense, saint and witz constitute conventionalized social interlocutors rather than personifications of ethnic ideals or models of absolute good and evil" (ibid.: 77).

In this context, the discussion concerning San Simón or Maximón, the Maya saint characterised by a Ladino look and Ladino clothes (see Mendelson 1959; 1965), provides a relevant case in point. The connection between Maximón and Judas has been interpreted as the representation of the relationship between the Indian and the Ladino and the cult of the saint as a form of the resistance of the oppressed against the oppressor (Nash 1994). To draw on Taussig's (1993) vocabulary, this has been seen as an example in which fetishisation and mimetisation (imitation and copying in the form of a figurine) of the Other attribute magic power to ethnic alterity and enable participation in that power. On the other hand, James MacKenzie (2009: 374) has argued that San Simón "is more than a symbol of resistance" and has compared the politicisation of the theme by some anthropologists to similar efforts in the cultural-activist Maya spirituality. Timothy Knowlton (2012) showed San Simón to have become increasingly disconnected from Ladino ethnicity, not just in the perception of Indian laymen, but also in that of Ladino spiritists. In his view, this process of indigenisation of a saint is a reflection of the progress of decolonisation: once material wealth and cultural capital are no longer exclusively held by Ladinos, the Indian saint can really become Indian, since he is as strong as the Maya identity. "Ironically, this same indigenization that decolonizes indigenous spiritualities empowers Ladino spiritist practice according to the logic that fetishizes alterity and attributes magical power to the ethnic Other" (ibid.: 243). Ethnicity has been reconfigured at the crossroads of two fields, the religious and the social, neither of which can be reduced to the other.

To summarise: the similarity between the concept of 'devilish' mine owners in the cosmology of the Andes and the Maya perception of Maximón as Judas or of the 'Ladino' lords of the mountains is significant. Given that such perceptions can be found even in Maya areas that have never had any mining industry, the explanation for this 
similarity can hardly be looked for in a resistance to the 'evil' mining economy. Furthermore, James E. Brady and Dominique Rissolo (2006) showed some of the pre-Columbian caves to have been dug for ritual, and not utilitarian, reasons; pilgrimages to these caves therefore seem to have been related to the religious need to enter the interior of the mountain and to their healing powers. The theory of the fetishisation of the Other, too, is not without problems: as shown by MacKenzie (2009) and Knowlton (2012), the interethnic, social and power relationships need not be the only and constitutive for the Maya saint cult.

The native perception of the mountain cannot be reduced to the categories of ethnicity or power relations, nor to a clear-cut cultural ideology. As noted by Wilson (1995: 53), the character of the tzuultaq'a is of a dual and contradictory nature: "It is both mountain and valley, male and female, spirit and matter, singular and multiple, benevolent and vengeful, indigenous and foreign, with a Q'eqchi' name and a Spanish saint's name, linking the heavens and earth". The mountains are "both good and evil, nurturing and destructive" (ibid.: 60). Just as Sallnow (1989: 218) has been searching for the meaning of Andean minerals within these minerals as such, I too believe that the meaning of Maya mountain deities should be chiefly seen in the very mountains. However, in order to refine the argument, let me first discuss the ethnography of the mountains and other important beings of the contemporary Maya world.

\section{MOUNTAINS AND SACRIFICES AMONG THE TRADITIONALIST MAYA}

In order to understand more deeply the content of Maya thought and practice concerning the power of the mountains, in this section I turn to some aspects of the traditionalist cosmology as I learned about it in the Akatek community. I will focus in particular on the native concept of and relation to divinity. In their prayers, rezadores express their respect for God and the World in its two halves - Earth and Sky - along with its four representations in time and space, the Bearers of the World (Cargadores del Mundo) and the Bearers of the Year (Cargadores del Año). In addition, they invoke other entities such as atmospheric phenomena, natural objects, ancestors, plants, animals or saints, including various images of Christ and Mary. The saints, who inhabit churches, chapels or the dwellings of certain people, are not mere tokens or 'symbols' referring to spiritual beings in a different world. The saints of the church in Chimbán clearly live there: they really are the statues in the boxes along its sides. Each of them came to Chimbán one day and settled down to stay - as long as good care is taken of him. The shamans take care of the saints, decorate them on feast days, pray and sacrifice candles and copal to them.

In Maya cosmology, certain entities, which are classified as 'material', 'lifeless' or 'unconscious' in the European worldview, are live beings, endowed with consciousness and volition, and thus capable of autonomous action. This is true not only of saints, but also of crosses and mountains. I was informed by Maya traditionalists that an old wooden cross may not simply be thrown out or destroyed; it has to stay on the spot together with the new one, or has to have another place assigned to it. Crosses are perceived as persons: as Oliver La Farge and Douglas Byers (1931: 186) note, "These crosses see, think, hear, and also speak to those shamans who know how to put them- 
selves in touch with them". Crosses are 'planted' like plants and decorated so as to resemble maize and trees (cf. Carlsen 1997: 60-61). Mountains, too, are not dead or passive objects, but living and active beings. They have souls and the capacity to act. The extreme importance of mountains in Maya lives is ethnographically well documented throughout the Sierra de los Cuchumatanes (see esp. Wagley 1957 [1949]; Watanabe 1990; Deuss 2007; Piedrasanta Herrera 2009).

The Maya suppose the masters of mountains to have the power to influence their lives: they are important and potent beings that need to be paid due respect (respeto) and with whom good and balanced relationships need to be fostered. Mountains are both bane and boon for the people: they bring devastating wind as well as the much needed rain, the bad luck of lost ways and good luck in hunting. Recklessness and distortion of the balance result in misfortunes and illnesses, at both the individual and collective levels (cf. López García and Metz 2002: 219; Hermesse 2011: 146-149). Failure to take care of a mountain, a cross or a saint may result in disease for the individual or bad luck for the entire community. Thus, the ritual of the advent of the Maya New Year, described in this paper, is a notable example of the ritualisation of the relationship between the shamans and the human community, on the one side, and the mountains, the World and God, on the other.

The words most commonly used by rezadores to explain why they do the things they do are costumbre and compromiso. The sacrifice on the mountain of K'utataj is a costumbre, a custom, something that simply needs to be performed and something that the ancestors did as well. To accept the office of rezador, to become responsible for performing rituals is a compromiso: a service, an obligation, a commitment. The Spanish word literally means 'mutual promise' and expresses the character of the Maya relationship to the divine with surprising accuracy. It represents a world in which its inhabitants, humans and deities, are analogically linked to and complement each other. Although deities are more powerful than humans, they are not substantially different: they live their lives, are endowed with conscience and volition and have their requirements and wishes. Indeed, humans might need deities to bring rain and good crops in order to be able to survive, but deities equally need humans to feed them (cf. Tedlock 1982: 77-82; Metz 2006: 125).

When rezadores perform sacrifices to crosses or mountains, they claim to be literally 'feeding them'; in their view, crosses and mountains 'eat' candles and copal and 'drink' turkey blood (cf. Wagley 1957 [1949]: 184; Piedrasanta Herrera 2009: 72). Humans and deities support each other; they depend on each other for their survival. This mutual commitment of beings dependent on each other really amounts to a relationship of 'compromise': a constant dialogue and search for agreement and conformity. By offering food, the shamans fulfil the duties that humans in general have to the other beings of the world. This is the way to ensure that the world will keep on its course and prevent it from ending. In sum, pilgrimage and sacrifice are conscious expressions of the continuation of the world and the continuation as such is not a matter of course.

In Maya cosmology, the mountains have been linked to caves as sources of water and rain for a long time (Bassie-Sweet 1996). Since pre-Columbian times, the mountains have expressed the power of the Earth and acted as life-givers, originators of livelihood and maize in the rain rituals (Brady and Prufer 2004). By the same token, the entry into the cave is an advance into the interior of the mountain and a physical approxi- 
mation to the cosmic powers of the Earth (Fischer 1999: 482). The mountain deities, thus, embody the fundamental importance of the mountains as such. In fact, it is mountains that surround human communities and that create their innate environment; it is mountains that determine the weather, bringing the much needed rain as well as destructive droughts, winds and storms; and it is mountains which provide their livelihoods to people, through soil fertility or as sources of timber and game. As a result, the mountain is not just a (cultural) representation of the world; it is also a(n) (existential) representation of the life in the world.

\section{BEYOND SOCIAL AND CULTURAL REDUCTIONISM}

The mountain masters play an important role in Maya cosmology. However, it was the rich, powerful and unpredictable whites who lent their faces to these native deities. This obviously gives rise to a theoretical discrepancy. On the one hand, the idea of the lord of the mountain could have a social origin; it can be thought of as the result of projecting the power relations between people onto the 'heavens'. On the other hand, the idea could also have religious roots, if it is understood as the result of a projection of spiritual relationships onto society. This is not merely a problem of materialism vs. idealism, but also a problem related to the 'function and origin' controversy. It is certainly true that the relationship between the Indian and the deity can be regarded as an analogy of the relationship between the Indian and the Ladino, and can be interpreted along the lines of unequal power distribution and ethnic differences. This analogy can sometimes be explained by the admiration of the richer and more powerful, or by fear of them; and sometimes by referring to the mechanism by which the subordination is affirmed, or to the instrument of resistance; or by fetishisation and imitation, or appropriation of the Other; or indeed, in many other ways.

Nevertheless, the search for the ultimate function or origin of a phenomenon is just as problematic as solving the materialism vs. idealism problem. Indeed, the answer need not be located within these oppositions but rather in the phenomenon as such, as it is, here and now; in other words, in how it lives in the people and what their experience of the world is. A phenomenological and existential approach to the life-world cannot enable rational terms like power to become "ontologically foundational to human sociality and history and [to subjugate] all other provinces of human life to them" (Jackson 2005: xxix). For the Maya, the mountains are an innate environment for human life: they are responsible for good and bad crops and life and death and, as a result, are factors of existential importance. In a very intimate fashion, they constitute the key components of the Maya life-world, which is characterised by the interaction and communication between humans and non-humans (cf. Astor-Aguilera 2010). As Jackson (2005: 186) would say, "being is not restricted to human being" since people interact with the environment and with others (for example ancestors, animals or plants); the social world, therefore, extends far beyond the world of humans. People "effectively redistribute being within the most intimate spaces of their lives, and imaginatively, practically and socially negotiate new relationships between external constraints and inner potentialities" (ibid.: 188). 
Few authors have paid as much attention to Maya mountain masters as Watanabe (1992) and Wilson (1995). In a first step, both researchers focused on ethnic identity and strived to distance themselves from the two most influential positions in this respect: from essentialism and historicism. For Watanabe (1992: 8), the problem could be summarised as follows: while the essentialists sought to interpret Maya culture as a static continuum, the historicists reduced it to an artefact of colonial dominance. Watanabe (ibid.: 12), however, situates Maya culture in the "existential relations because a focus on the conjunction of place, people, and premise enables - indeed demands - concern for what motivates individuals and groups to live in communities in the first place". Although historicist and relational views dominate current anthropological research, Wilson (1995: 313) argues that "[they] tend to neglect indigenous agency and deny the autonomy of nativistic cultural constructions consciously developed by indigenous peoples". Thus, he suggests adopting a synthetic approach, combining the force of cultural continuity and the influence of interethnic relationships (ibid.: 321-322). The aim of this study has, however, not so much been to attempt a Wilson-style synthesis, as it has been to try, inspired by Watanabe, to overcome the theoretical controversy by emphasising the existential relations between people and the physical as well as the spiritual world that they inhabit.

Taken to their extremes, the two positions above lead to - cultural or social - reductionism. Moreover, I think that the European assumptions underlying these positions result in ethnocentrism once we try to project them onto Maya cosmology and ritual, as they depart from their original cultural context. Social reductionism rests on the assumption that what are of primary importance and constitutive to life are the relations between people. For the Maya, however, it is not exclusively people whom they come across, socially interact and communicate with. Maya cosmology does not consider humans to be radically different from other beings of the world. Humans, of course, have their specific traits, but they are not separated from the world, nor do they differ from animals, plants or minerals by being conscious, volitional and able to act. The entire universe of the Maya, both as a whole and in its individual parts, is endowed with soul and consists of beings with varying degrees of importance and power. Mountains also have a critical impact on human lives and good and balanced relationships with them are therefore of the essence. Basically, what lurks behind European social reductionism, which is built around the dichotomies of animated/unanimated or active/ passive, is anthropocentrism.

Cultural reductionism is based on the assumed existence of a spiritual entity, a transcendent and powerful culture hovering over poor individuals. Such a culture almost has the qualities of an unchanging divine idea separated from the changing world. Yet, any thinking that places a divinity in some other distant world to have it merely represented in this world by an imperfect image, icon or 'symbol' is foreign to the Maya. Saints, crosses and mountains inhabit the same world as humans and animals. These beings have personalities, consisting of (very often multiple) 'physical' and 'spiritual' parts. One cannot say that, for the Maya, stones are physical and objective entities, while angels are spiritual and subjective entities, and humans a combination of both: the body/spirit and object/subject dichotomies are characteristic of European rather than Maya thought. The transcendence of the spiritual and divine loses its rationale in a world where all beings have their objective and passive, as well as subjective and 
active components: the spirit is not something that would transcend its carnal bearer and the deity is not something that would transcend this world by its position, essence or power. Deities are not essentially different and incomparably more powerful; they do not transcend humans due to being radically different. Fundamentally, what lurks behind European cultural reductionism is theism. ${ }^{4}$

\section{THE EXISTENTIAL ECONOMY OF 'WORKING THE WORLD'}

In this paper, I have discussed the extremely important role of the mountain deities in Maya thought and practice. Providing two ethnographic examples of Maya mountain pilgrimage, I have demonstrated a certain amount of similarity between its traditionalist and Pentecostal versions. To answer the question of the source of the mountain fascination, I have examined both the continuity/discontinuity as well as essentialism/ historicism debates. Far from cultural or social reductionism, my intention here has been to present Maya mountain deities as living beings and Maya pilgrimages as lived practice. I wanted to approach Maya cosmology through a lens that does not turn people and mountains into mere puppets of cultural ideas and patterns or mere objects of social dominance and resistance, but instead, one that shows them as active agents in the field of relations between the beings of the world. On a theoretical level, the data might indicate ways in which the concepts of 'sacred', 'divine' or 'transcendental' can be grasped without falling into cultural or social reductionism and, consequently, ethnocentrism. I suggest that these concepts should be viewed as related to the experiential basis of existence, which cannot be reduced either to the ideological or the political dimension. The divine therefore needs to be situated in the sphere of the life-world and the everyday.

By stressing the phenomenal and existential aspects of thought and practice associated with the mountain and other deities, I wanted to challenge the widespread interpretation of communication with nature-based divinity as referring to (being and epiphenomenon of) 'something else'. I suggest that this kind of communication must be seen as an actual encounter endowed with an intense experience of interaction concerning the mutual dependence between the human and non-human beings of the world. In a similar way, Cannell (1999) discusses the nature of truly emotional relationships between Bicolano healers, their patients and spirit-companions in her book Power and Intimacy in the Christian Philippines. She argues that the encounters are often represented as the mutual (though not always conscious or intentional) checking of power and influence, which entails an eventuality of changing the agents involved (ibid.: 230-231). What is stressed here, however, is the large degree of ambiguity, tension and uncertainty within the interactions. The experience of such an exchange is described by terms such as 'help' and 'oppression', or 'love' and 'pity': consequently, the system under which such an exchange takes place "has to be understood as an emotional economy as much as a political economy" (ibid.: 107).

I believe that Cannell's observations appear suitable for the Maya concept of relationship as well. But I would go even further and argue that there may also be a significant existential aspect in such an 'exchange' or 'economy'. What I mean by this is that the diverse and complex emotional relationships between the agents grow out of the 
everyday experience related to the existential dealings between people and the physical and spiritual world they inhabit. As I hope to have shown with respect to the Maya life-world, the mountains can be responsible for good or bad crops, life or death, and can constitute factors of fundamental existential importance. I also hope to have demonstrated the extent to which the Maya see their being-in-the-world as delicate and fragile. For them, human beings are emplaced in a world that is not given; it is not something unchanging, definitive or self-evident. In its time dimension, the world has a cyclical character, where the end of each cycle entails the possibility of something going wrong. As noted by MacKenzie (2009: 372), the world is not heading towards a definite goal and nothing in it happens on its own: "A costumbrista worldview, I argue, while concerned with 'order' and harmony in the cosmos, views this as 'work': the practice of human (and other) subjects". When dealing with Maya pilgrimage, sacrifice and intimacy with the mountains, we are concerned with an authentic existential economy.

As I have argued, the cultural and social function/origin distinction could be bridged by the concept of active and lived participation in the course of the world - working the world. Here, people are involved in a process of interpreting signs from diverse beings interconnected by the fabrics of mutual relationships. In this respect, Jackson (2005: $\mathrm{xx}$ ) is certainly not wrong in describing human existence as "the struggle for being in a world where being is mutable and unstable, and where controlling and comprehending the forces that shape one's destiny is an unremitting task". At least for the Maya, the emplacement of people into an ever-changing unpredictable world inhabited by various beings and powers takes the form of a dynamic negotiation; then, "the struggle for being is better understood as a continual, if frequently unreflective, quest for some sense of balance between being an actor and being acted upon" (ibid.: 182). The delicate interdependence and complementarity of humans and non-humans, embedded in the fragile uncertainty concerning the continuation of the world is a form of intimacy which is best defined as the experience of participating in being. Given this state of affairs, the dynamics of the interaction and communication between the beings of the world should not be seen as a conflict between humans and the world, but rather as their co-existence.

\section{NOTES}

1 Religious change and religious pluralism are among the key characteristics of contemporary Guatemala. Today, Protestant converts represent some $50 \%$ of population in many Maya communities, with the rest divided among Catholics, Maya revivalists and Maya traditionalists (i.e. costumbristas who follow custom or the 'old ways'). For more detailed information on Maya traditionalism, see the section "Mountains and Sacrifices among the Traditionalist Maya".

2 Cf. Deuss (2007: 143-152) for another account of this experience.

3 Chinax is one of the four Year Bearers. The Year Bearers are considered 'Chiefs' of the twenty Day Lords - the named days of the Maya calendar - and it is always one of them who ushers in the Maya New Year.

4 These topics have, of course, already been discussed in anthropology, especially by authors who could be regarded as falling under the 'anthropology of ontology' label (cf. Scott 2013). The work of Eduardo Viveiros de Castro (1998) is a prime example in this respect, as it distinguishes between a representation and a perspective, and thereby ceases to prioritise representational thinking over bodiness as a locus of ontological differentiation. 


\section{REFERENCES}

Adams, Abigail E. 2001. Making one our Word: Protestant Q'eqchi' Mayas in Highland Guatemala. - Holy Saints and Fiery Preachers: The Anthropology of Protestantism in Mexico and Central America, edited by James W. Dow and Alan R. Sandstrom. Westport, CT: Praeger Publishers, 205-233.

Annis, Sheldon. 1987. God and Production in a Guatemalan Town. Austin, TX: University of Texas Press.

Astor-Aguilera, Miguel A. 2010. The Maya World of Communicating Objects: Quadripartite Crosses, Trees, and Stones. Albuquerque, NM: University of New Mexico Press.

Bassie-Sweet, Karen. 1996. At the Edge of the World: Caves and Late Classic Maya World View. Norman, OK: University of Oklahoma Press.

Brady, James E. and Keith M. Prufer, eds. 2004. In the Maw of the Earth Monster: Mesoamerican Ritual Cave Use. Austin, TX: University of Texas Press.

Brady, James E. and Dominique Rissolo. 2006. A Reappraisal of Ancient Maya Cave Mining. Journal of Anthropological Research 62: 471-490.

Brady, James E. and George Veni. 1992. Man-made and Pseudo-karst Caves: The Implications of Subsurface Features within Maya Centers. - Geoarchaeology 7 (2): 149-167.

Cannell, Fenella. 1999. Power and Intimacy in the Christian Philippines. Cambridge: Cambridge University Press.

Carlsen, Robert S. 1997. The War for the Heart and Soul of a Highland Maya Town. Austin, TX: University of Texas Press.

Cook, Garrett W. 2000. Renewing the Maya World: Expressive Culture in a Highland Town. Austin, TX: University of Texas Press.

Cook, Garrett W. 2001. The Maya Pentecost. - Holy Saints and Fiery Preachers: The Anthropology of Protestantism in Mexico and Central America, edited by James W. Dow and Alan R. Sandstrom. Westport, CT: Praeger Publishers, 147-168.

Desjarlais, Robert and C. Jason Throop. 2011. Phenomenological Approaches in Anthropology. Annual Review of Anthropology 40: 87-102.

Deuss, Krystyna. 2007. Shamans, Witches, and Maya Priests: Native Religion and Ritual in Highland Guatemala. London: Guatemalan Maya Centre.

Dow, James W. 2005. The Expansion of Protestantism in Mexico: An Anthropological View. Anthropological Quarterly 78 (4): 827-850.

Dow, James W. and Alan R. Sandstrom, eds. 2001. Holy Saints and Fiery Preachers: The Anthropology of Protestantism in Mexico and Central America. Westport, CT: Praeger Publishers.

Engelke, Matthew. 2004. Discontinuity and the Discourse of Conversion. - Journal of Religion in Africa 34 (1-2): 82-109.

Fischer, Edward F. 1999. Cultural Logic and Maya Identity. - Current Anthropology 40: 473-499.

Fischer, Edward F. 2001. Cultural Logics and Global Economics: Maya Identity in Thought and Practice. Austin, TX: University of Texas Press.

Gross, Toomas. 2009. Farewell to Fiestas and Saints? Changing Catholic Practices in Contemporary Rural Oaxaca. - Journal of Ethnology and Folkloristics 3 (1): 3-19.

Gross, Toomas. 2012. Incompatible Worlds? Protestantism and Costumbre in the Zapotec Villages of Northern Oaxaca. - Folklore: Electronic Journal of Folklore 51: 191-218.

Harris, Olivia. 1989. The Earth and the State: The Sources and Meanings of Money in Northern Potosi, Bolivia. - Money and the Morality of Exchange, edited by Jonathan Parry and Maurice Bloch. Cambridge: Cambridge University Press, 232-268.

Hermesse, Julie. 2011. Hibridación de la cosmovisión maya contemporánea: Estudio etnográfico de San Martín Sacatepéquez, Guatemala. - Mesoamérica 53: 157-188. 
Jackson, Michael, ed. 1996. Things as They Are: New Directions in Phenomenological Anthropology. Bloomington, IN: Indiana University Press.

Jackson, Michael. 2005. Existential Anthropology: Events, Exigencies and Effects. New York, NY: Berghahn Books.

Knowlton, Timothy. 2012. Ethnicity, God Concepts, and the Indigenization of a Guatemalan Popular Saint. - Journal of Anthropological Research 68: 223-247.

Kray, Christine A. 2007. A Practice Approach to Ritual: Catholic Enactment of Community in Yucatán. - Anthropos 102: 531-545.

La Farge, Oliver and Douglas Byers. 1931. The Year Bearer's People. New Orleans, LA: The Tulane University of Louisiana.

López García, Julián and Brent E. Metz. 2002. Primero Dios: Etnografía y cambio social entre los mayas ch'orti's del oriente de Guatemala. Guatemala: FLACSO.

MacKenzie, C. James. 2009. Judas off the Noose: Sacerdotes Mayas, Costumbristas, and the Politics of Purity in the Tradition of San Simón in Guatemala. - Journal of Latin American and Caribbean Anthropology 14: 355-381.

Mendelson, E. Michael. 1959. Maximon: An Iconographic Introduction. - Man 59 (1): 57-60.

Mendelson, E. Michael. 1965. Los escándalos de Maximoón: Un estudio sobre la religión y la visión del mundo en Santiago Atitlán. Guatemala: Semenario de Integración Social Guatemalteca.

Metz, Brent E. 2006. Ch'orti'-Maya Survival in Eastern Guatemala: Indigeneity in Transition. Albuquerque, NM: University of New Mexico Press.

Nash, June. 1979. We Eat the Mines and the Mines Eat Us: Dependency and Exploitation in Bolivian Tin Mines. New York, NY: Columbia University Press.

Nash, June. 1994. Judas Transformed. - Natural History 103 (3): 46-53.

Oakes, Maud. 1951. The Two Crosses of Todos Santos: Survivals of Mayan Religious Ritual. Princeton, NJ: Princeton University Press.

Piedrasanta Herrera, Ruth. 2009. Los Chuj: Unidad y rupturas en su espacio. Guatemala: ARMAR Editores.

Pugh, Timothy W. 2009. Maya Sacred Landscapes at Contact. - Maya Worldviews at Conquest, edited by Leslie G. Cecil and Timothy W. Pugh. Boulder, CO: University Press of Colorado, 317-334.

Reina, Ruben. 1966. The Law of the Saints: A Pokomam Pueblo and its Community Culture. Indianapolis, IN: Bobbs-Merrill.

Robbins, Joel. 2003. On the Paradoxes of Global Pentecostalism and the Perils of Continuity Thinking. - Religion 33 (3): 221-231.

Robbins, Joel. 2007. Continuity Thinking and the Problem of Christian Culture: Belief, Time, and the Anthropology of Christianity. - Current Anthropology 48 (1): 5-38.

Sallnow, Michael J. 1989. Precious Metals in the Andean Moral Economy. - Money and the Morality of Exchange, edited by Jonathan Parry and Maurice Bloch. Cambridge: Cambridge University Press, 209-231.

Scott, Michael W. 2013. What I'm Reading: The Anthropology of Ontology (Religious Science?) Journal of the Royal Anthropological Institute 19: 859-872.

Siegel, Morris. 1941. Religion in Western Guatemala: A Product of Acculturation. - American Anthropologist 43 (1): 62-76.

Taussig, Michael. 1980. The Devil and Commodity Fetishism in South America. Chapel Hill, NC: University of North Carolina Press.

Taussig, Michael. 1993. Mimesis and Alterity: A Particular History of the Senses. New York, NY; London: Routledge.

Tedlock, Barbara. 1982. Time and the Highland Maya. Albuquerque, NM: University of New Mexico Press. 
Viveiros de Castro, Eduardo. 1998. Cosmological Deixis and Amerindian Perspectivism. - Journal of the Royal Anthropological Institute 4: 469-488.

Wagley, Charles. 1957 [1949]. Santiago Chimaltenango: Estudio antropológico-social de una comunidad indígena de Huehuetenango. Guatemala: Seminario de Integración Social Guatemalteca.

Watanabe, John M. 1990. From Saints to Shibboleths: Image, Structure, and Identity in Maya Religious Syncretism. - American Ethnologist 17: 131-150.

Watanabe, John M. 1992. Maya Saints and Souls in a Changing World. Austin, TX: University of Texas Press.

Watanabe, John M. and Edward F. Fischer, eds. 2004. Pluralizing Ethnography: Comparison and Representation in Maya Cultures, Histories, and Identities. Santa Fe, NM: School of American Research Press.

Wilson, Richard. 1995. Maya Resurgence in Guatemala: Q'eqchi' Experiences. Norman, OK: University of Oklahoma Press. 